\title{
The Use of BBC (Box, Board, and Comics) Media in The Systems of Linear Equation
}

\author{
P D Widyastuti ${ }^{1, a)}$, M Mardiyana ${ }^{1}$, and D R S Saputro ${ }^{2}$ \\ ${ }^{1}$ Departement of Mathematics Education, Universitas Sebelas Maret, \\ J1. Ir. Sutami 36A Kentingan Jebres Surakarta 57126, INDONESIA \\ ${ }^{2}$ Departement of Mathematics Education, Universitas Sebelas Maret \\ Jl. Ir. Sutami 36A Kentingan Jebres Surakarta 57126, INDONESIA \\ ${ }^{3}$ Departement of Mathematics, Universitas Sebelas Maret \\ Jl. Ir. Sutami 36A Kentingan Jebres Surakarta 57126, INDONESIA \\ E-mail: widya.puspita9@gmail.com
}

\begin{abstract}
Mathematics is one of the lessons in school. Starting from elementary school, junior high school, senior high school, even college. Mathematics is abstract and identic with numbers, so the author guessed that maybe this is the reason why students consider that mathematics is a difficult lesson. In fact, the learners deliver the material step by step. First, the teacher introduced something concrete to the students (related to the surrounding environment). After that, teacher introduced something more abstract to the students. Sometimes, the transition from concrete to abstract become the problem in the learning process. One of the materials that convert concrete to abstract is systems of linear equations in 8th grade because in this stage students are introduced to more coefficients and variables. This article will discuss how to use media in the form of $B B C$ (Box, Board, and Comics) on systems of linear equations. This research is about Research and Development $(R \& D)$. The procedures of comics followed the $A D D I E$ model which included analysis, design, development, implementation, and evaluation. This research aims to create a valid media based on the validation by the and students' responses which can be proven that BBC (Box, Board, and Comics) media are interesting and worthy to use in the classroom.
\end{abstract}

\section{Introduction}

Mathematical learning is done step by step starting from the concrete to the abstract. First, the teacher teaches students by taking examples from daily life. Beni Yusepa [9] stated that real-world-oriented learning made the students easier to build their knowledge. After that, the teacher switches to the abstract domain by starting to use a variety of symbols that we usually know as variable. In fact, the transition from concrete to abstract often becomes a problem for students. The low score of the students of SMP Negeri 12 Surakarta in the National Examination 2016/2017 compared to other schools in the system of linear equations becomes one of the sign that students do not understand about the material.

Al J et al [1] stated that the difficulties in algebra are: 1) arithmetic operations; 2) the notion of variables; 3) algebraic expressions; 4) the different meanings of the equal sign; and 5) mathematization. The junior secondary level is the level which students 
begin to learn something abstract. This phase is not easy because each student has different abstraction abilities. The process of abstraction is important so the teachers are required to use the appropriate method / instructional media to avoid errors of the concept. Glenda A dan Margaret W [3] stated that tools are helpful in communicating ideas that are otherwise difficult to talk about or write. Teachers and students can use representations such as stories, pictures, symbols, concrete objects, and virtual manipulatives to assist in communicating their thinking to others.

The $\mathrm{BBC}$ media is started from the boxes. The boxes used to motivate students to be actively involved in understanding the concept of the system of linear equations. The activity aims to introduce students something abstract. The author entered two different types of objects into each box (e.g., four pencils and six books in the first box and three pencils and four books in the second). Then the author wrote the price list on each box. Students will be invited to determine what the price of one pencil and one book. For more details, please note figure 3 .

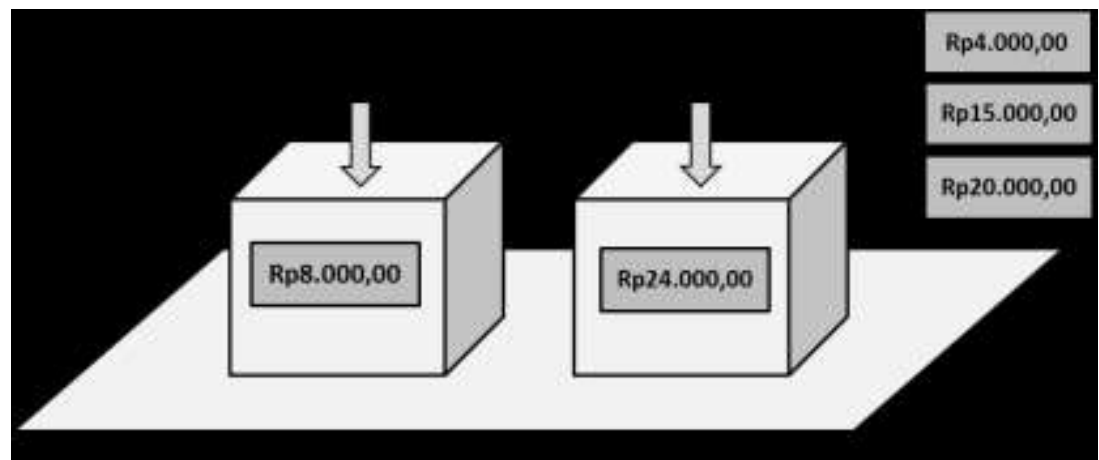

Figure 3. Box is the first step which uses in BBC Media

The use of the board is to make students understand what methods are used to solve the system of linear equations. The author prepared a whiteboard with four different methods such as: a) graphical; b) elimination; c) substitution; d) and mix. For more details, please note the Figure 4.

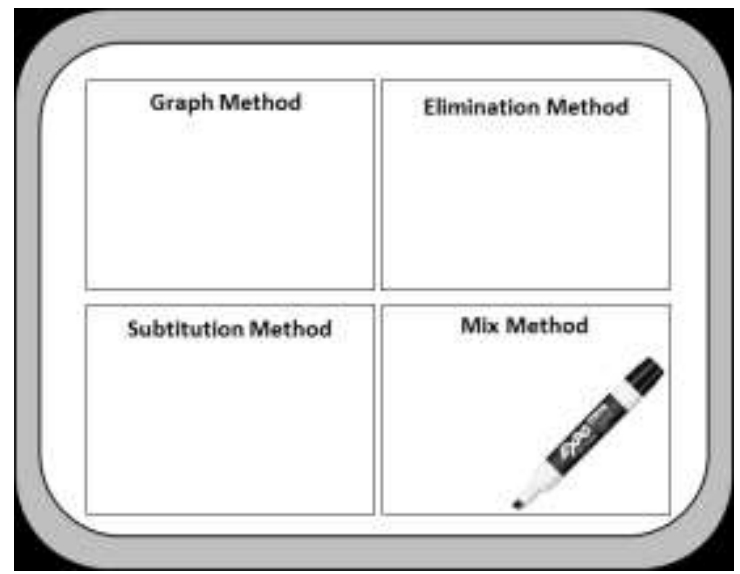

Figure 4. Board is used to introduce students about the methods 
After the students understand the concepts and methods of completion, the author gives the comics so that the students can more understand the material by using it. The comics has more detail such as explanation, questions and discussions, and exercises. It was chosen as a solution of systems of linear equations because the characteristics of both are similar, the material can be brought to real life so the author expected that it can simplify the students to translate the material from concrete form to abstract. For more details, please note the figure 5 .

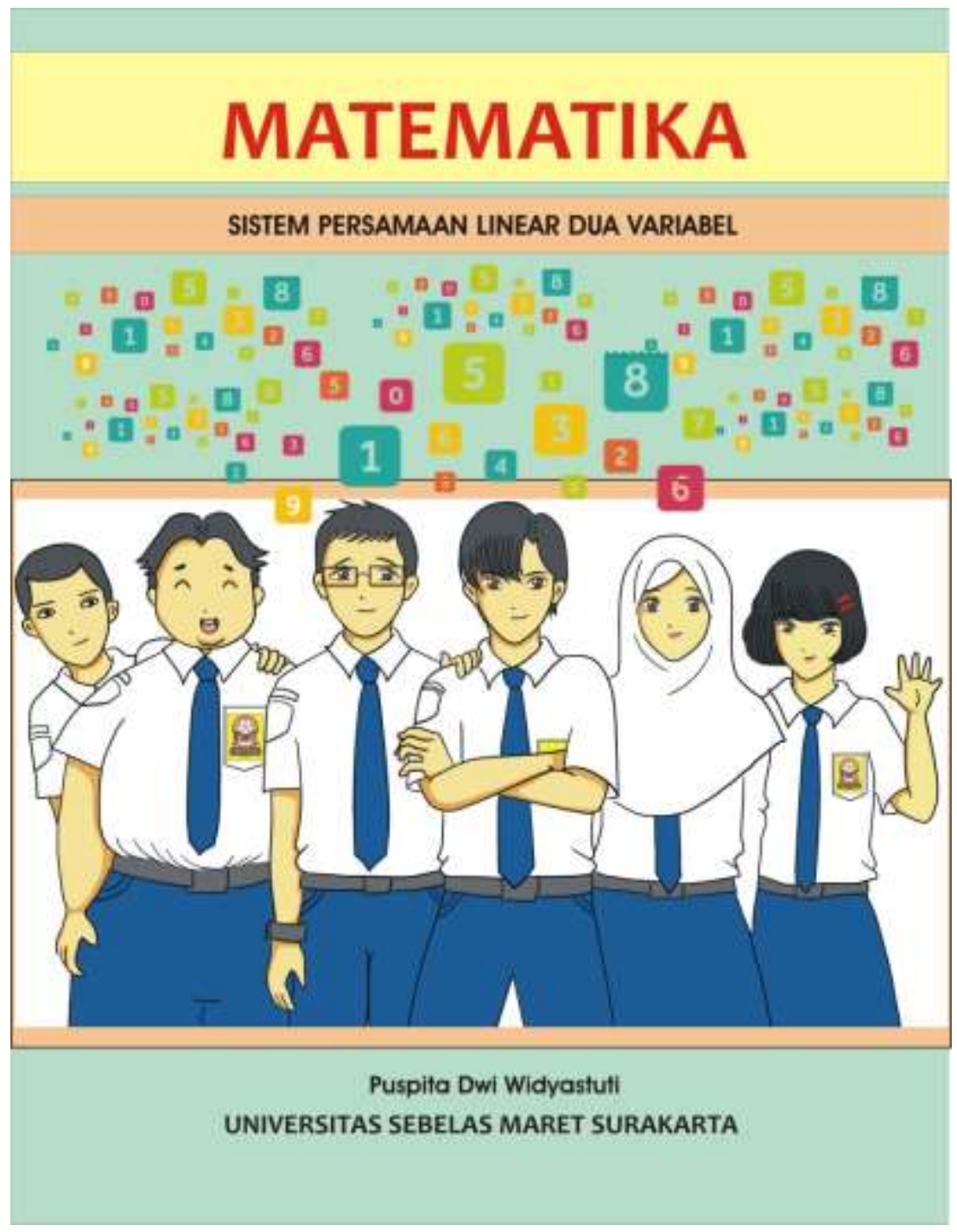

Figure 5. Front Cover of The Comic

\section{Experimental Method}

This research is a Research and Development ( $R \& D)$. Sugiyono[8] stated that Research and Development is a process or steps to develop a new product or refine an existing product which can be justified. The procedures of BBC media followed the ADDIE model which included analysis, design, development, implementation, and evaluation. The analysis is a process of defining what will be learned by study 
participants, such as a) needs analysis; b) problem identify; c) and task analysis. The design is the process to combine learning material and the media so the result can reach the expected learning objectives. At the design stage, the author required the clarification of learning programs so the program can achieve the expected learning objectives. The development stage includes activities to create and modify teaching materials to achieve the expected learning objectives. The implementation is the process to deliver the material to the students. The last stage is the evaluation. This stage can be defined as a process to give the value to a learning media.

The reason for using the $A D D I E$ model is because it is one of the most widely used models. Based on the opinion from Nada Aldoobie [2] which stated that the $A D D I E$ model is one of the most commonly used models to produce effective product. The research was conducted in SMP Negeri 12 Surakarta because this school has the low score in National Exam 2016/2017 compare to other schools in Surakarta. The author aims to make a valid and practical learning media from the results of validation and students' responses.

\section{Result and Discussion}

Based on the observation results, the author got information that students have difficulties in a) translating problems related to daily life into the mathematical symbols; b) solve problems using certain methods; c) and operating algebraic forms. The results of the observations encourage researchers to find solutions to the problems that occur in the classroom. After the media had been finished, validation was done by the experts to check whether the media is feasible/valid for use or not. The purpose of this questionnaire is to create a practical media for students. Revisions to the validation and distribution of questionnaires are still underway to improve the product. These are the results of validation with material and media experts.

Table 1. Validation of Material Expert

\begin{tabular}{lllll}
\hline \multirow{2}{*}{ Rated Aspects } & \multicolumn{2}{c}{ Average } & \multirow{2}{*}{ Information } \\
\cline { 2 - 3 } & Expert 1 & Expert 2 & \multicolumn{2}{|c}{3.6} \\
Presentation Techniques & 4 & 3.6 & 3.8 \\
Learning Presentation & 4 & 3.75 & 3.88 \\
Supporting The Presentation & 4 & 3.5 & 3.75 \\
Material Coverage & 4 & 4 & 4 \\
Conformity of the Item with the Material & 4 & 4 & 4 \\
Contextuality & 4 & 3.8 & 3.9 \\
Conformity with student development & 4 & 4 & 4 \\
Communicative & 4 & 4 & 4 \\
Interactive Dialog & 4 & 4 & 4 \\
Straightforward & 4 & 3 & 3.5 \\
Conformity of language rules & 4 & 3.67 & 3.83 \\
\hline & \multicolumn{3}{c}{ Total Avarage } & 3.88 very valid \\
\hline
\end{tabular}


Table 2. Validation of Media Expert

\begin{tabular}{lccl}
\hline \multicolumn{1}{c}{ Rated Aspects } & \multicolumn{2}{c}{ Average } & \multirow{2}{*}{ Information } \\
\cline { 2 - 3 } & Expert 1 & Expert 2 & \\
\hline Learning Design & 4 & 3.83 & 3.9 \\
Visual Quality & 4 & 3.6 & 3.8 \\
The usefulness of math comics & 3.7 & 3.7 & 3.7 \\
\hline & & Total Avarage & 3.8 very valid \\
\hline
\end{tabular}

The last result from validation table and students' responses showed that BBC media is valid and practical to use. Based from the students' responses, the author got some comments by the students such as: a) the box and board help students to understand the concept of systems of linear equations of two variables; b) the comics has interesting drawings and storylines; b) comics can make it easier for students to understand difficult material; and d) students suggest that the media can be produced more. The validation results with media experts on mathematical comics showed that comics are interesting to use both inside and outside the classroom, but there are some suggestions and improvements such as: a) the role of box, board, and comics in learning process; b) the paper size of comics; c) the proportion between drawing and writing should be balanced; d) correction of comic-related coloring; and e) the substance of comics.

\section{Conclusion}

Based on the results obtained, it can be concluded that the use of BBC media is suitable to students, especially on the material system of two linear equations. The results of calculations obtained from the validators and students' responses have also shown satisfactory results. BBC media considered very well used both inside and in the classroom, the use of box and board make the students easy to understand the concepts of systems of linear equations of two variables. The storyline of the comics does not make students feel saturated like a book package in general.

\section{References}

[1] Al J, Paul D, and Marja H P 2014 Difficulties in initial algebra learning in Indonesia (Mathematics Education Research Group of Australasia)

[2] Aldoobie N 2015 ADDIE Model vol 5 no 6 (USA : American International Journal of Contemporary Research)

[3] Anthony G and Walshaw M 2009 Characteristics of Effective Teaching of Mathematics: A View from the West Vol 2 No 2 (New Zealand: Journal of Mathematics Education) pp.147-164

[4] Bolton C and Gary 2012 Connecting Through Comics: expanding Opportunities for Teaching and Learning (USA: David Publishing) p 389-395

[5] Daryanto 2010 Media Pembelajaran (Yogyakarta: Gava Media)

[6] Lee P Y 2007 Teaching Secondary School Mathematic: A Resource Book (Singapore: McGraw-Hill)

[7] Packalen L dan Odoi F 2005 Comics With Attitude (New York)

[8] Sugiyono 2013 Metode Penelitian Pendidikan (Pendekatan Kuantitatif, Kualitatif, 
dan $R \& D)$ (Bandung : Alfabeta)

[9] Yusepa B 2016 Kemampuan Abstraksi Matematis Siswa SMP kelas VIII vol 1 no 1 (Journal of Research in Mathematics Learning and Education) 